University of Chicago Law School

Chicago Unbound

Journal Articles

Faculty Scholarship

2007

\title{
On Discounting Regulatory Benefits: Risk, Money, and Intergenerational Equity
}

Arden Rowell

Cass R. Sunstein

Follow this and additional works at: https://chicagounbound.uchicago.edu/journal_articles

Part of the Law Commons

\section{Recommended Citation}

Arden Rowell \& Cass R. Sunstein, "On Discounting Regulatory Benefits: Risk, Money, and Intergenerational Equity," 74 University of Chicago Law Review 171 (2007).

This Article is brought to you for free and open access by the Faculty Scholarship at Chicago Unbound. It has been accepted for inclusion in Journal Articles by an authorized administrator of Chicago Unbound. For more information, please contact unbound@law.uchicago.edu. 


\title{
On Discounting Regulatory Benefits: Risk, Money, and Intergenerational Equity
}

\author{
Cass R. Sunstein $\dagger$ and Arden Rowell $\dagger \dagger$
}

\begin{abstract}
There is an elaborate debate over the practice of "discounting" regulatory benefits, such as environmental improvements and decreased risks to health and life, when those benefits will not be enjoyed until some future date. Economists tend to think that, as a general rule, such benefits should be discounted in the same way as money; many philosophers and lawyers doubt that conclusion on empirical and normative grounds. Both sides frequently neglect a simple point: if regulators are interested in how people currently value risks that will not come to fruition for a significant time, they can use people's current willingness to pay to reduce those risks. And if the question involves people's willingness to pay in the future, what is being discounted is merely money, not regulatory benefits as such. No one seeks to discount health and life as such-only the money that might be used to reduce threats to these goods. If willingness to pay to reduce risk is the appropriate metric for allocating regulatory resources, discounting merely adjusts that metric to make expenditures comparable through time. To be sure, cost-benefit analysis with discounting can produce serious problems of intergenerational equity; but those problems, involving the obligations of the present to the future, require an independent analysis. Failing to discount will often hurt, rather than help, future generations, and solutions to the problem of intergenerational equity should not be conflated with the question of whether to discount.
\end{abstract}

\section{INTRODUCTION}

Suppose that a proposed regulation will not produce benefits for many years; suppose too that an agency is asked to engage in some form of cost-benefit analysis before it proceeds with the regulation. Future monetary costs will be discounted on the theory that a dollar today is worth more than a dollar in twenty years. But what should the agency do about such future benefits as improved health or averted deaths? Should these too be discounted, or should a death in 2025 be treated the same as a death today?

In terms of ultimate outcomes, the choice matters a great deal. If an agency chooses not to discount, the benefits calculation will shift dramatically from what it would be if the agency chooses a discount

$\dagger$ Karl N. Llewellyn Distinguished Service Professor, Law School and Department of Political Science, University of Chicago.

†† Associate, Perkins Coie LLP, Seattle, Washington. Thanks to Blake Roberts for excellent research assistance; to Matthew Adler, Robert Hahn, Bernard Harcourt, John Morrall, Eric Posner, Richard Posner, and David Weisbach for valuable comments; and to participants in an exceedingly helpful work-in-progress lunch at the University of Chicago Law School. We are also grateful to participants in the Symposium on Intergenerational Equity and Discounting at the University of Chicago Law School. 
rate of, for example, 10 percent. If a human life is valued at $\$ 8$ million, and no discount rate is applied, a life saved 100 years from now is worth the same expenditure today as a life saved now: $\$ 8$ million. But at a discount rate of 10 percent, the same life would justify a modern expenditure of only $\$ 581$. For a regulation whose effects would be felt centuries from now, any reasonable discount rate will reduce apparently substantial benefits to close to nothing. ${ }^{2}$

The Office of Management and Budget (OMB) suggests that agencies should prepare analyses using rates of both 3 percent and 7 percent, ${ }^{3}$ departing from its suggested 10 percent rate in the 1980s. But these numbers remain controversial. ${ }^{4}$ Consider the fact that the midpoint -5 percent - would ensure that, if a human life is valued at $\$ 8$ million, 100 deaths in 100 years would be worth only $\$ 6.25$ million today. The point has obvious implications for problems with long time horizons, such as global climate change. If the most serious effects of climate change will be felt in 2100 or beyond, a decision to discount at any significant rate-even 3 percent-will dramatically reduce the monetized gain of emissions reduction strategies. ${ }^{5}$

In any case, agencies are not bound by OMB guidelines, and in recent years, their own rates have ranged from as low as 3 percent (Food and Drug Administration, Department of Housing and Urban Development) to as high as 10 percent (Environmental Protection Agency). In fact, the same agency sometimes uses different discount rates for no apparent reason. The EPA, for example, used the 10 percent rate for regulating emissions from locomotives, but selected 7

1 See Michael Gerrard, Demons and Angels in Hazardous Waste Regulation, 92 Nw U L $\operatorname{Rev} 706,742-43$ (1998) (applying these figures for the value of a discounted human life in the context of waste management).

2 See Martin L. Weitzman, “Just Keeping Discounting, But ...", in Paul R. Portney and John P. Weyant, eds, Discounting and Intergenerational Equity 23, 23 (Resources for the Future 1999) (noting that any reasonable discount rate will make events a few centuries from now not count at all).

3 For the 7 percent rate, see Office of Management and Budget, Circular A-94, Guidelines and Discount Rates for Benefit-Cost Analysis of Federal Programs 8 (1992), available at 57 Fed $\operatorname{Reg} 53519,53523$ (1992). For a more recent suggestion that agencies use both 3 percent and 7 percent, see Office of Management and Budget, Circular A-4, Regulatory Analysis 33-34 (2003), online at http://www.whitehouse.gov/omb/circulars/a004/a-4.pdf (visited Jan 23, 2007).

4 See Richard W. Parker, Grading the Government, 70 U Chi L Rev 1345, 1370-71 (2003) (criticizing discount rates greater than 5 percent as far above the consumption rate of interest of 2 or 3 percent, which most economists believe is the appropriate rate for discounting future benefits).

5 For an illuminating discussion, see generally Frank Ackerman and Ian Finlayson, The Economics of Inaction on Climate Change: A Sensitivity Analysis (Global Development and Environment Institute Working Paper No 06-07, 2006), online at http://www.ase.tufts.edu/gdae/ Pubs/wp/06-07EconomicsInaction.pdf (visted Jan 23, 2007).

6 See Edward R. Morrison, Comment, Judicial Review of Discount Rates Used in Regulatory Cost-Benefit Analysis, 65 U Chi L Rev 1333, 1366-67 (1998). 
percent for regulating drinking water and 3 percent for regulating lead-based paint.' In this domain, government practice is erratic. Key questions are therefore: What discount rate, if any, should agencies choose ${ }^{8}$ Do life and health require some special discount rate or no discount rate at all? What is the relationship between discount rates and the rights and interests of future generations?

We shall attempt to make progress on these questions by offering two claims. The first claim is that if the interests of future generations are put to one side, and if we focus solely on risks faced by those now living, regulatory benefits should be discounted at the same rate as money, and for a simple reason: existing valuations depend on willingness to pay, and discounting those valuations is simply a matter of discounting money.' There are two different possibilities here. Suppose, first, that regulators are interested in establishing how much people currently are willing to pay to reduce risks that will not materialize for a long time. (For example, the question may involve people's current exposure to levels of arsenic that create a $1 / 100,000$ risk of cancer twenty years hence.) If so, they should measure people's present willingness to pay to eliminate future harms, and use that figure for purposes of valuation. ${ }^{10}$ In that event, the government is not itself discounting; it is incorporating the discount rates of the people it is attempting to protect. Suppose, second, that regulators are interested in people's future willingness to pay to reduce risks. (The question may involve people's exposure, twenty years hence, to levels of arsenic that will create a $1 / 100,000$ risk of cancer twenty years from that time.) If

\footnotetext{
$7 \quad$ Id at 1337.

8 Valuable treatments include Richard Revesz, Environmental Regulation, Cost-Benefit Analysis, and the Discounting of Human Lives, 99 Colum L Rev 941, 977-81 (1999) (discussing discount rates as part of an agency's cost-benefit analysis of regulations and analyzing how circumstances should affect the choice of discount rate); Morrison, Comment, $65 \mathrm{U}$ Chi L Rev at 1348-49 (cited in note 6) ("As a threshold matter, it seems unreasonable for agencies not to discount benefits to future generations in their cost-benefit analyses of proposed rules.").

9 We do not attempt to specify the appropriate monetary discount rate. For discussion, see generally Portney and Weyant, eds, Discounting and Intergenerational Equity (cited in note 2) (compiling the views of twenty economists concerning the purpose, utility, and determination of discount rates). See also Richard A. Posner, Catastrophe: Risk and Response 150-55 (Oxford 2004) (demonstrating that the weight given to the welfare of future generations affects the determination of discount rates); Daniel Farber and Paul A. Hemmersbaugh, The Shadow of the Future: Discount Rates, Later Generations, and the Environment, 46 Vand L Rev 267, 289-96 (1993) (assessing the use of discount rates in regulation particularly with regard to environmental policy); William J. Baumol, On the Social Rate of Discount, 58 Am Econ Rev 788, 789-96 (1968) (identifying the appropriate discount rate for a public project as that which correctly gauges the social opportunity cost of the project).

10 If there is inadequate information, or a problem of bounded rationality such as myopia, existing figures might be questioned. But this problem does not involve governmental "discounting"; it involves using, and if necessary correcting, individual assignments of monetary values for benefits that will be enjoyed in the future.
} 
so, money is what will be spent in the future, and it makes sense to discount money. So long as valuations are based on private willingness to pay, there is no special problem with discounting money; any objection is to the use of willingness to pay, not to discounting as such.

The second claim is that while cost-benefit analysis with discounting can produce serious problems of intergenerational equity, these problems are not best addressed by refusing to discount. We will show that under identifiable circumstances, regulatory decisions based on discounting will produce morally unjustified actions by the present generation at the expense of posterity. But refusing to discount does not solve this problem; in many cases, it will injure, rather than promote, the interests of future generations. The task of fulfilling the obligations owed by the present to the future is exceedingly important, but it is not appropriately handled by a refusal to discount. We shall attempt to clarify the nature of those obligations while also showing the need to distinguish them from the separate question of discounting.

To understand these claims, and their implications for regulatory agencies, reviewing courts, and the general idea of "sustainable development," we need to back up a bit.

\section{DEBATES}

Everyone agrees that money should be discounted. The simplest reason is that it can be invested and made to grow. It is better to have $\$ 1000$ today than $\$ 1000$ in ten years, if only because $\$ 1000$ today can be made to be worth much more than $\$ 1000$ a decade hence. But for life and health as such, discounting is greatly disputed in both theory and practice. In an important case, a federal court said that discounting is necessary to provide an "apples-to-apples comparison" of costs and benefits, suggesting that agencies are legally required to use the same discount rate for health and safety benefits as for dollars. "Other decisions have insisted on careful explanations for whatever discount rates agencies choose. ${ }^{12}$ Economists tend to believe that the argument for discounting is obvious, though the consensus has started to unravel

11 See Corrosion Proof Fittings v EPA, 947 F2d 1201, 1218 (5th Cir 1991) (noting that if an agency chooses to discount the effects of a regulation, it must discount not only the costs, but the benefits as well, in an attempt to avoid skewed results).

12 Compare Natural Resources Defense Council v Herrington, 768 F2d 1355, 1413-14 (DC Cir 1985) (rejecting the Department of Energy's 10 percent discount rate because it was conclusory and because the Department did not carefully establish its discount rate or explain its decision "intelligently"), with Northern California Power Agency v FERC, 37 F3d 1517, 1522-24 (DC Cir 1994) (holding the FERC's use of a uniform discount rate for both private and public consumers to be sufficiently supported). 
in the last decade. ${ }^{13}$ Philosophers ${ }^{14}$ and lawyers ${ }^{15}$ are often skeptical about discounting. Philosophers have raised serious doubts about the idea that a future death or illness should be discounted in the same way as money. ${ }^{16}$ Lawyers as well have questioned that idea, suggesting that it depends on contentious empirical or normative assumptions. ${ }^{17}$

\section{A. Objections and Paradoxes}

A central objection is that a life in 2025 does not seem to be "worth less" than a life today. If ten people are killed twenty years hence, the outcome is not worse than if ten people are killed tomorrow. Thus one critic asks: "What is wrong with discounting numbers of lives saved? One obvious problem is that death does not recognize human accounting conventions and death does not discount." ${ }^{, 18}$ In the same vein, Ackerman and Heinzerling object that "the choice implicit in discounting

13 See Robert W. Hahn, The Economic Analysis of Regulation: A Response to the Critics, 71 U Chi L Rev 1021, 1026-27 (2004) (arguing for discounting because "consumers are not indifferent between consuming a dollar today and a dollar next year," and rejecting arguments for either a lower discount rate than commonly used or no discount rate); John J. Donohue III, Why We Should Discount the Views of Those Who Discount Discounting, 108 Yale L J 1901, 1903 (1998) (arguing that discounting is essential to better regulation because it "helps [agencies] to rationalize their regulatory agenda and enables independent analysts to evaluate the soundness of particular regulations"). Various positions are presented in Portney and Weyant, eds, Discounting and Intergenerational Equity (cited in note 2), with recognition of some of the underlying complexities. See generally Paul R. Portney and John P. Weyant, Introduction, in Portney and Weyant, eds, Discounting and Intergenerational Equity 1, 5 (cited in note 2) (stressing in particular "the unease even the best minds of the profession feel about discounting, due to the technical complexity of the issues and to their ethical ramifications").

14 See Tyler Cowen and Derek Parfit, Against the Social Discount Rate, in Peter Laslett and James S. Fishkin, eds, Justice between Age Groups and Generations 144, 148 (Yale 1992) (finding unpersuasive the philosophical argument for discounting on the ground that the correlation between discounting and future social benefit is imperfect and based on faulty logic); Derek Parfit, Reasons and Persons 357 (Oxford 1984) (arguing that "the Social Discount Rate is indefensible" because "[t]he present moral importance of future events does not decline at a rate of $n$ per cent per year").

15 See Frank Ackerman and Lisa Heinzerling, Priceless: On Knowing the Price of Everything and the Value of Nothing 186-87 (New Press 2004) (arguing against discounting because certain problems, like climate change, may become irreversible and thus not be adequately addressed if discounting is applied, and because the market cannot tell individuals how to make tradeoffs between the present and distant generations); Sidney A. Shapiro and Robert L. Glicksman, Risk Regulation at Risk: Restoring a Pragmatic Approach 118-19 (Stanford 2003); Frank Ackerman and Lisa Heinzerling, Pricing the Priceless, 150 U Pa L Rev 1553, 1570-73 (2002) (criticizing discounting as undervaluing future generations and environmental protection).

16 See Cowen and Parfit, Against the Social Discount Rate at 160 (cited in note 14) (arguing that a genetic deformity twenty years from now is not "worth" less than a genetic deformity today; by contrast, a dollar twenty years from now is worth less than a dollar today).

17 See Revesz, 99 Colum L Rev at 977 (cited in note 8) (arguing that the methodology currently used to establish the discount rate, which holds the utility derived from living constant over time, overstates that rate).

18 Parker, 70 U Chi L Rev at 1374 (cited in note 4) (asserting that "discounting lives is misleading," as the value placed on future welfare is a moral choice, not an economic one). 
is between preventing harms to the current generation and preventing similar harms to future generations. Seen in this way, discounting looks like a fancy justification for foisting our problems off onto the people who come after us." They emphasize that with "a discount rate of five percent, for example, the death of a billion people 500 years from now becomes less serious than the death of one person today."20

Defenders of discounting have responded that a refusal to use a discount rate creates a number of logical and practical conundrums. For instance, a refusal to discount might require truly extraordinary sacrifices from the present for the sake of the (infinite) future. On one view, the failure to discount would leave all generations at a subsistence level of existence, because benefits would be postponed perpetually for the future." "Negative discount rates would mean that we should always postpone consumption now in favour of consumption tomorrow, leaving current generations perhaps at some subsistence level of consumption. Worse, the postponement is perpetual." At the very least, a zero discount rate might "bias[] cost-benefit analysis in favor of rules that impose excessive sacrifices on the current generation."

On the other hand, it has been argued that a failure to discount the monetized equivalent of regulatory benefits would lead to less regulation, not more. If regulators are indifferent between lives saved now and lives saved in the future, but discount costs at some positive rate, then it makes sense for them to delay life-saving expenditures indefinitely, simply because the cost-benefit ratio will (always) be better in the future. Under this view, "the discounting of costs but not benefits ... has a paralyzing effect on a decisionmaker.... For any attractive program, there is always a superior delayed program which should be funded first. The result is that no program with a finite starting date can be selected." ${ }^{24}$

19 Ackerman and Heinzerling, $150 \mathrm{U}$ Pa L Rev at 1571 (cited in note 15).

20 Id.

21 See David Pearce and R. Kelly Turner, Economics of Natural Resources and the Environment 223-24 (Hopkins 1990) (arguing that with a negative discount rate, current generations would remain in subsistence because consumption would always be postponed until tomorrow).

22 Id.

23 Morrison, Comment, $65 \mathrm{U}$ Chi L Rev at 1349 (cited in note 6).

24 Emmett B. Keeler and Shan Cretin, Discounting of Life-Saving and Other Nonmonetary Effects, 29 Mgmt Sci 300, 303 (1983) (arguing that regulators will never enact programs if they discount costs but not benefits). The argument is criticized in Revesz, 99 Colum L Rev at 989-92 (cited in note 8) (arguing that, in the context of environmental problems, a failure to act in the present could yield exponentially worse or irreversible problems in the future, because "costs and damages would vary over time if the problem[s] were left unattended").

Ackerman and Heinzerling discuss Keeler and Cretin's claim and reject it, in part on the ground that allowing numerous current deaths would be politically unacceptable. See Ackerman and Heinzerling, Priceless at 193-94 (cited in note 15). But the claim is one of the logical implica- 
In any case, defenders of discounting have argued that instead of discounting lives as such, regulators might simply use the future discounted (monetary) cost of saving lives at the time when the lives are saved-an approach that is mathematically identical and hence produces the same analysis. ${ }^{25}$ Summarizing a range of arguments, a general overview suggests that failure to permit a discount rate will ensure that any cost-benefit analysis "fails to account for the opportunity cost of resources that are diverted from private investment toward investment in the proposed rule," and could therefore "lead the agency to adopt rules that reduce the welfare of future generations, because the resources could have been invested in assets with higher rates of return.. ${ }^{26}$ But for good reasons, these arguments have yet to convince the numerous critics of discounting. As we shall see, it is by no means clear that the relevant resources will be "invested" for the benefit of future generations.

Responding to the controversy, some prominent analysts have distinguished between "descriptive" and "prescriptive" approaches. Under descriptive approaches, the discount rate is chosen by examining the rate of return to capital that has been invested in a range of possible assets. This is the standard approach of those who advocate

tions of refusing to discount, and the fact that it entails a politically unacceptable outcome does not mean that it is wrong.

25 See, for example, John F. Morrall III, Saving Lives: A Review of the Record, 27 J Risk \& Uncertainty 221, 229-30 (2003) (analyzing data regarding "[o]pportunity costs per statistical life saved" for different agency regulations).

26 Morrison, Comment, $65 \mathrm{U}$ Chi L Rev at 1349 (cited in note 6) (arguing that policy judgments and methodology "dictate the choice between the two competing approaches to discounting"). This argument has been used by OMB itself, see OMB, Circular A-4 at 35 (cited in note 3), and it is the closest to the argument we make here. But if our argument is correct, it is unnecessary to speak of opportunity costs, because what is being discounted is the monetary value of the risk itself. For questions of intergenerational equity, the argument from opportunity costs is insufficient, because we do not know that those savings will be invested for posterity's benefit rather than consumed. See Cowen and Parfit, Against the Social Discount Rate at 152 (cited in note 14) ("When benefits to be consumed are received later, this may involve no opportunity costs."). Note that many people believe that future risks are unlikely to come to fruition because new technologies will permit us to prevent them. As later discussed in the text, however, this is not a point about discounting itself.

27 See William Cline, Discounting for the Very Long Term, in Portney and Weyant, Discounting and Intergenerational Equity 131, 135, 137-39 (cited in note 2) (discussing the differences between the prescriptive and descriptive approaches and proposing a "workable compromise for intergenerational discounting"); K.J. Arrow, et al, Intertemporal Equity, Discounting, and Economic Efficiency, in James P. Bruce, Hoesung Lee, and Erik F. Haites, eds, Climate Change 1995: Economic and Social Dimensions of Climate Change 125, 131-34 (Cambridge 1996) ("The prescriptive approach, which is usually associated with a relatively low discount rate, begins with a social welfare function ... constructed from ethical principles," while "[t]he descriptive approach implicitly aims to maximize the economic resources available to future generations, allowing them to decide how to use these resources."). 
discounting. ${ }^{28}$ Under prescriptive approaches, the discount rate is selected on the basis of ethical judgments about the duties of one generation to those that succeed it. These approaches can lead to dramatically different rates. ${ }^{29}$ But there is a serious difficulty with this distinction: any descriptive approach must ultimately be defended in prescriptive terms. It remains disputed whether the best prescriptive arguments require abandonment of what emerges from the preferred descriptive approach.

\section{B. Building on Preferences}

An alternative possibility is to attempt to bracket the moral debates by investigating people's actual preferences in this domain. Emphasizing the importance of those preferences, some defenders of discounting have attempted to show that people do discount future lives and the interests of future generations. On a standard view, "a zero discount rate is inconsistent with the observable behavior of individuals, which is arguably the best guide for policy in a democratic state." ${ }^{31}$ The word "arguably" suggests the normative problem in this context: why should the interests of future generations be determined by consulting the preferences of the present generation? Those preferences might well be self-interested. Even if there is a degree of altruism, there is no reason to think that the (bounded) altruism of the present should settle the moral entitlements of the future. ${ }^{32}$

In any case, individual preferences in this context are not easy to identify, and they appear to be subject to framing effects. In an influential paper, Maureen Cropper and her coauthors conclude that people are indifferent between saving one life today and saving forty-five

28 See, for example, Robert C. Lind, A Primer on the Major Issues Relating to the Discount Rate for Evaluating National Energy Options, in Robert C. Lind, et al, eds, Discounting for Time and Future in Energy Policy 21 (Resources for the Future 1982).

29 See Portney and Weyant, Introduction at 4 (cited in note 13) ("[T] he prescriptive approach will result in the selection of a lower discount rate than would result from the use of the descriptive approach."). A helpful overview can be found in Her Majesty's Treasury, Stem Review: The Economics of Climate Change 31-32, 41-52 (2006), online at http:/www.hm-treasury.gov.uk/independent_reviews/ stern_review_economics_climate_change/sternreview_index.cfm (visited Jan 29, 2007).

30 See Raymond J. Kopp and Paul R. Portney, Mock Referenda and Intergenerational Decisionmaking, in Portney and Weyant, Discounting and Intergenerational Equity 87, 91-92 (cited in note 2) (arguing for mock referenda that take the citizenry's actual preferences into account).

31 Morrison, Comment, 65 U Chi L Rev at 1349 (cited in note 6).

32 See Stern Review at 31 (cited in note 29) (noting that "it is possible that people actually do place less value on the welfare of future generations" but that "it is hard to see any ethical justification for this"). This objection raises serious questions about the approach in Kopp and Portney, Mock Referenda and Intergenerational Decisionmaking (cited in note 30). For a related criticism of democratic arguments for discounting, see Cowen and Parfit, Against the Social Discount Rate at 146 (cited in note 14) ("When those affected have no vote, the appeal to democracy provides no answer."). 
lives in one hundred years - a conclusion that, if sound, would have concrete implications for the appropriate discount rate. ${ }^{33}$ The conclusion was based on a study that asked people whether they would prefer a program that saves " 100 people now" or one that saves a substantially larger number " 100 years from now." Yet other ways of framing the same problem yield radically different results. For example, most people consider "equally bad" a single death from pollution next year and a single death from pollution in 100 years $-a$ finding that implies no preference for members of the current generation. ${ }^{34}$ Measurements of people's judgments about obligations to future generations are influenced by framing effects. ${ }^{35}$ For this reason, it is far from clear that judgments about discounting can be rooted in actual preferences.

\section{Health versus Money, Latent Harms versus Future Generations}

Within the legal literature, the most influential and elaborate treatment of discounting future benefits has been offered by Dean Richard Revesz. ${ }^{36}$ Revesz makes two central arguments. First, he contends that the primary reasons for discounting monetary benefits do not apply to risks to life and health. ${ }^{37}$ Money is discounted for two reasons: first, it can be invested, and second, most people have a "pure" time preference for current over future consumption..$^{38}$ But human lives cannot be invested, and a life lost twenty years in the future cannot be "recovered" by investing some sum, or some person, in the present. (Human beings cannot be put in banks-or if they can, they are unlikely to grow there.) Nevertheless, Revesz acknowledges that people may well have a pure time preference that would treat a future risk as less troublesome than a present risk. ${ }^{39}$ Michael Moore and W.

33 Maureen L. Cropper, et al, Preferences for Life Saving Programs: How the Public Discounts Time and Age, 8 J Risk \& Uncertainty 243, 244, 254 (1993) (stating that individuals' "discount rate for lives saved is almost as high as their real discount rate for money").

34 See Shane Frederick, Measuring Intergenerational Time Preference: Are Future Lives Valued Less?, 26 J Risk \& Uncertainty 39, 40-41, 43 (2003) (describing the results of a study that used seven different methods to assess "intergenerational time preferences," each of which yielded "dramatically different" results).

35 For a similar result, see Jonathan Baron, Can We Use Human Judgments To Determine the Discount Rate?, 20 Risk Analysis 861,862 (2000) (noting that the problem of basing discount rates on human judgments is that such judgments elicit "dramatically inconsistent results").

36 See generally Revesz, 99 Colum L Rev 941 (cited in note 8).

37 Id at $974-77$ ("I can invest $\$ 100$ today at a $3.5 \%$ interest rate and have about $\$ 200$ in twenty years. I cannot invest the utility that I derive from living a year at present and obtain, twenty years later, the utility that I would then derive from living two years.").

38 For a suggestion that a pure time preference is irrational, see Cowen and Parfit, Against the Social Discount Rate at 154-55 (cited in note 14) (reporting that, though it is irrational, many people prefer to have benefits accrue to them sooner rather than later, even if they know that this will make the benefits smaller).

39 Revesz, 99 Colum L Rev at 997-1002 (cited in note 8). 
Kip Viscusi, for example, have investigated the empirical question, and find a real discount rate of about 2 percent, one that "accords roughly with financial market interest rates for the period, once these nominal rates are adjusted for inflation." ${ }^{40}$ Revesz argues that the existence of such a time preference justifies some discount rate for future harms that will occur to people now living."

To see the practical implication, consider the case of arsenic regulation. In its rationale for the regulation, the EPA treats an arsenic death in the future as equivalent to an arsenic death in the present, even though an arsenic death is likely to come, if it does come, decades after current exposures. ${ }^{42}$ Revesz's argument suggests that the EPA's refusal to discount the latent harms from arsenic exposure is wrong, even arbitrary; some kind of discount rate is clearly appropriate. But Revesz does not argue that the EPA should adopt a discount rate that is equivalent to the appropriate discount rate for money. He contends, not implausibly, that there is no reason in the abstract to think that the time preference for health risks is the same as the time preference for dollars; and because there is no investment opportunity, any discount rate for health risks may well be smaller than the market rate of return typically used to discount money. Hence the use of a market rate of return, on Revesz's view, is likely to produce a significant undervaluation of regulatory benefits that will be enjoyed in the future. ${ }^{43}$ This is an important conclusion, because it suggests that current government practice should be substantially changed in a way that would justify a number of regulations that cannot now satisfy a cost-benefit test.

Second, Revesz contends that it is important to distinguish between latent harms and risks to future generations. ${ }^{44}$ An environmentally induced illness today is worse than an environmentally induced illness in twenty years; it is for this reason that some kind of discount

40 Michael J. Moore and W. Kip Viscusi, Discounting Environmental Health Risks: New Evidence and Policy Implications, 18 J Envir Econ \& Mgmt S-51, S-61 (1990) (analyzing a "calculation of the value of longevity using a willingness to pay approach").

41 Revesz, 99 Colum L Rev at 984 (cited in note 8) (arguing that such a discount rate reflects that individuals derive less utility from a year in the future than from a present year).

42 National Primary Drinking Water Regulations; Arsenic and Clarifications to Compliance and New Source Contaminants Monitoring, 66 Fed Reg 6976, 7013 (2001), codified at 40 CFR $\S \S 9,141,142$ :

Although the [EPA's Science Advisory Board] recommended accounting for latency in a primary benefits analysis, the [EPA] believe[s] that, in the absence of any sound scientific evidence on the duration of particular latency periods for arsenic related cancers, discounted benefits estimates are more appropriately accounted for in a sensitivity analysis.

43 See Revesz, 99 Colum L Rev at 983 (cited in note 8) (noting that OMB's approach to discounting undervalues human life, as it fails to account for economic growth).

44 See id at 987 ("[I]t is not defensible to argue that the value assigned by the regulatory process to a human life should be independent of when an individual's life-years are lost."). 
rate makes a great deal of sense for latent harms. But for risks to future generations, Revesz believes that the argument for discounting is much more fragile. ${ }^{45}$ Why should a death of a ten-year-old in 2040 count less than a death of a ten-year-old today? Revesz concludes that there is no good answer to this question, and hence that the standard idea of discounting is not properly applied to harms faced by members of future generations. ${ }^{46}$

In its guidance to federal agencies, OMB is alert to Revesz's concerns but disagrees, calling for the same discount rate for money as for other goods, briskly referring to opportunity costs: "It is true that lives saved today cannot be invested in a bank to save more lives in the future. But the resources that would have been used to save those lives can be invested to earn a higher payoff in future lives saved. ${ }^{.47}$ In any case, people prefer immediate health gains to equivalent health gains in the future. ${ }^{48}$ And because a failure to discount would produce "perverse" results, OMB suggests that agencies should follow the "professional consensus that future health effects, including both benefits and costs, should be discounted at the same rate." errs in suggesting that there is such a consensus. ${ }^{50}$

\section{DisCOUNTING MONEY:THE LAST GENERATION}

We believe that both the defenders and the critics of discounting neglect an exceedingly simple point, one that supports the conclusion that an apples-to-apples comparison is indeed necessary. The point is this: willingness to pay is the foundation for valuation, and current

45 See id at 987-1003 (refuting various arguments in favor of discounting risks to future generations, and asserting that no expenditures would pass a cost-benefit test were such a practice observed).

46 See id at 1005-09 (contending that if the current generation's actions impose costs on future generations, there is no simple way to compensate these future generations). Revesz does argue for a limited role for discounting in the intergenerational context, suggesting, for example, that present generations should not "spend more when we can achieve the same result for less," and that present generations might well prefer to face environmental harms in return for "the fruits of greater investments in technological innovation." Id at 1008. These suggestions are very much in the spirit of our discussion in Part IV below.

47 OMB, Circular A-4 at 34 (cited in note 3) (concluding that intergenerational discounting will protect the interests of the current and future generations at the same time).

48 Id (reasoning that this kind of pure time preference makes discounting appropriate).

49 Id (claiming that, without discounting, attractive investments in health improvements would be perpetually delayed into the future).

50 OMB overstates the professional consensus. See Portney and Weyant, Introduction at 5 (cited in note 13) (describing "the unease even the best minds of the profession feel about discounting, due to the technical complexity of the issues and to their ethical ramifications"); William D. Nordhaus, Discounting and Public Policies That Affect the Distant Future, in Portney and Weyant, eds, Discounting and Intergenerational Equity 145, 149 (cited in note 2) ("[C]onventional benefitcost analyses are rules of thumb for decisionmaking. .. . But they cannot substitute for judgment."). 
willingness to pay can be used to measure both risks that will come to fruition immediately and risks that will come to fruition in the future. If future willingness to pay is what is involved, then future money should be discounted just like other forms of money. Any discount rate is based on individual preferences, not on government discounting. Individual preferences might be questioned, if (for example) people tend to be myopic, showing little concern for their future selves. But this issue, involving the possibility of hyperbolic discounting of the future in general, is the relevant one; it does not involve government discounting of lives and health as such.

To separate this argument from intergenerational issues, to which we turn in Part IV, let us suppose that the practice of discounting is proposed, but only for those people who are now living. Imagine that the question involves the practices of what is, in some part of the world, the Last Generation-a generation of living people who will have no successors."

For the Last Generation, the problem is essentially solved by only one step: acceptance of the claim, now standard in the federal government and not challenged by many critics of discounting, that statistical risks should be turned into monetary equivalents. ${ }^{52}$ It is entirely unnecessary to speak of opportunity costs, as OMB does, or to ask, as Revesz does, whether the arguments that apply to money also apply to health and life. The reason is that what is being measured is always money, and never health or life as such. When agencies apply a discount rate to monetized regulatory benefits, they are discounting the relevant monetary amounts, not life or health.

To understand this point, it is necessary to see how regulators translate reductions of risk into monetary amounts. The answer comes from two kinds of evidence. The first and most important involves real-world markets, producing evidence of compensation levels for actual risks. In the workplace and for consumer goods, additional safety has a price; market evidence is investigated to identify that

51 See Richard Dubourg and David Pearce, Paradigms for Environmental Choice: Sustainability versus Optimality, in Sylvie Faucheux, David Pearce, and John L. Proops, eds, Models of Sustainable Development 21, 24 (Edward Elgar 1996) (“[M]aximizing a single utility function ... over infinite time cannot help but suggest that we are dealing with a single generation which exists forever, or even a single individual.").

52 Of course there is a separate controversy over the monetization of risks to health and life, see Ackerman and Heinzerling, Priceless at 188-91 (cited in note 15) (arguing against the monetization of risks to health and life, "[s]ince lives are not money, and do not have a meaningful price"), but that objection to discounting purports to be separate from the controversy.

53 See W. Kip Viscusi, Fatal Tradeoffs: Public and Private Responsibilities for Risk 59-65 (Oxford 1992) (analyzing seventeen studies on individuals' risk-dollar tradeoff in the labor market to determine their "implicit value of injury"). 
price. ${ }^{54}$ The second kind of evidence comes from contingent-valuation studies, asking people how much they are willing to pay to reduce statistical risks. ${ }^{55}$ Both of these approaches are controversial, of course, and rightly so. ${ }^{56}$ However the controversies are resolved, the use of these figures grows out of the simple idea that people should not be forced to pay for risk protection they do not want."

Currently, regulators use this evidence to calculate the amounts that people are willing to pay to avoid certain categories and levels of risk. These amounts produce the "value of a statistical life" (VSL). Once an agency has identified the relevant studies, the calculation of VSL is a product of simple arithmetic. The EPA, for instance, relies on studies of actual workplace risk, attempting to determine how much workers are paid to assume mortality hazards. ${ }^{59}$ If workers must be paid $\$ 600$, on average, to eliminate a risk of death of $1 / 10,000$, the VSL would be said to be $\$ 6$ million. It should be clear, however, that the very idea of valuing a statistical life is highly misleading; no one is "valuing life." The real issue involves the valuation of statistical risks. It is not accurate to say that a life is being valued at $\$ 6$ million. It would be much more accurate to say that for risks of $1 / 10,000$, the average (or median) monetary value in the relevant population is $\$ 600$ - or that for risks of $1 / 100,000$, the average (or median) monetary value is $\$ 60$.

Once regulatory benefits have been monetized in this way, regulators are no longer discounting actual risks to life or health. Instead, they are using people's willingness to pay to avoid those risks. There are two possibilities here, and they are analytically distinct. First, regulators might be monetizing both harms that will occur soon and risks

54 A valuable and comprehensive overview can be found in W. Kip Viscusi and Joseph E. Aldy, The Value of a Statistical Life: A Critical Review of Market Estimates throughout the World, 27 J Risk \& Uncertainty 5, 5 (2003) (reviewing "evidence on market choices that involve implicit tradeoffs between risk and money" to determine the value of a statistical life, which can "provide governments with a reference point for assessing the benefits of risk reduction efforts").

55 See, for example, James Hammitt and Jin-Tau Liu, Effects of Disease Type and Latency on the Value of Mortality Risk, 28 J Risk \& Uncertainty 73, 74 (2004) ("We use contingent valuation (CV) to test for effects of disease type and latency on individual willingness to pay (WTP) to reduce risks of developing a fatal cancer or other chronic, degenerative disease through exposure to environmental pollution.").

56 See Ackerman and Heinzerling, $150 \mathrm{U}$ Pa L Rev at 1522-78 (cited in note 15) (criticizing the monetization of risks for numerous reasons, most notably that human life is invaluable).

57 Of course this claim would not justify current practice if the figures are based on a lack of information or bounded rationality. For discussion of some of the complexities here, see Cass $\mathbf{R}$. Sunstein, Valuing Life: A Plea for Disaggregation, 54 Duke L J 385, 403 (2004) (arguing that willingness to pay numbers are relevant only if they "reflect a rational tradeoff by informed workers").

58 For an overview, see id at 398-400.

59 For further discussion, see Viscusi, Fatal Tradeoffs at 74 (cited in note 53) (noting that this "recognition of the nonpecuniary aspects of life is an important advance"). 
that will not turn into harms for a long time ("latent harms"). They might use current willingness to pay to value both of these. For harms that will occur soon, existing evidence can be used to measure people's willingness to pay. For risks that will turn into harms in the future, regulators can work with people's current willingness to pay to eliminate risks that will not materialize until a certain number of years in the future. Both market evidence and contingent-valuation studies can be enlisted to determine the appropriate values.

The labor market, for example, exposes people to risks that might materialize immediately and risks that will not turn into harms until some time in the future; and in principle, the resulting evidence might be measured to obtain the appropriate values. In addition, it would be simple to design a contingent-valuation study to determine people's current willingness to pay to avoid mortality risks of $1 / 100,000$ that would come to fruition five, ten, fifteen, and twenty years hence. Of course, any such evidence would involve people's own discount ratestheir own willingness to pay less (money) for future benefits than for present benefits. Recall that one study finds a 2 percent discount rate on the part of ordinary people, one that does not seem obviously irrational, and that can be used without any government discounting at all. ${ }^{60}$ In drawing on evidence of this kind, government is not generating a special discount rate for mortality or health; instead it is incorporating people's own judgments about the proper monetary valuation of benefits that will be enjoyed in the future.

To be sure, there are serious practical problems in determining the relevant values. It is possible that the labor market studies are too "noisy" to permit confident judgments about current valuations of future risks. Bounded rationality may create a real problem either for such studies or for contingent valuation. For reductions in risk that cannot come to fruition until a decade or more hence, there may be distinctive kinds of bounded rationality. If, for example, people display hyperbolic discounting, ${ }^{61}$ treating the future as if it were worth very little, we might not want to use the resulting judgments for purposes of policy. But these are fairly conventional difficulties with the use of willingness to pay, and they do not suggest that there are any particular problems with discounting life and health. People may display hyperbolic discounts rates for future money, not merely for future improvements in life and health; and we are speaking here of their cur-

60 See generally Moore and Viscusi, $18 \mathrm{~J}$ Envir Econ \& Mgmt S-51 (cited in note 40). If government itself discounted these figures, it would be involved in "double discounting."

61 See Viscusi, Fatal Tradeoffs at 145 (cited in note 53) (arguing that "individuals are likely to place an inefficiently low weight on benefits to future generations"). 
rent judgments about how much they are willing to pay to reduce future risks. Money is what is involved; discounting is merely a tool that makes amounts of money comparable through time. The real question is how to produce usable estimates of people's current willingness to pay to prevent future harms.

Suppose, however, that regulators are interested not in current monetary valuation of latent harms, but in future monetary valuations of such harms. The question might be not how much people are now willing to pay to prevent a harm that will occur twenty years from now, but how much people, part of the Last Generation but ten years hence, will be willing to pay to eliminate a risk that will produce harm occurring either immediately or still further in the future. (Hence we must distinguish between future valuations of then-current risks and future valuations of then-future risks.) Any judgments about the resulting amounts will have a speculative character, of course. Perhaps regulators should attempt to determine how much people would now be willing to pay to eliminate the future risks, in which case government itself need not discount at all. Perhaps regulators should attempt to determine how much people would be willing to pay, in the future, to eliminate those risks when they are encountered. If regulators attempt the latter approach, they will have to project future income growth (which will increase valuations). But once the relevant amounts are generated-and this is the key point-they will be monetary, and they must be discounted.

In discounting these monetized regulatory benefits, regulators are doing nothing more controversial than discounting money. It is appropriate to discount the money that people will be willing to spend, twenty years hence, on refrigerators, automobiles, movies, books, education, and medicine. The same is true of the money that people are willing to spend to avoid risk. All money can be invested and made to grow. Everyone agrees that for this reason, if for no other, $\$ 100$ today is worth more than $\$ 100$ in twenty years.

It follows that to produce valuations for the Last Generation, there is no need to identify logical conundrums or implausible outcomes that seem to follow from a failure to discount. Only two steps are necessary: an appreciation of the theory that underlies current practice, and an understanding that what is involved, always, is money, and not life, health, or the environment as such. To be sure, we have drawn a distinction between current willingness to pay to reduce future harms and future willingness to pay to reduce future harms.

62 We are putting to one side unusual cases in which, for reasons of self-control or otherwise, people might prefer future money to current money. 
Regulators do not appear to have distinguished between these two sets of problems, which raise distinctive challenges. But the key point is that money is involved in both cases.

Return in this light to the question of latent harms, and suppose that for the Last Generation it is necessary to assign monetary values to a risk, such as the cancer risk from current consumption of arsenic in drinking water, that will inflict harm twenty years hence. Suppose that ordinarily $\$ 8$ million is the appropriate VSL - that is, suppose that people are now willing to pay $\$ 80$ to eliminate a $1 / 100,000$ risk of mortality today, and that the relevant mortality risk is $1 / 100,000$. If the issue is people's current willingness to pay to prevent a $1 / 100,000$ risk that will not impose harm for twenty years, there is an empirical challenge, which is to elicit that amount. Almost surely, it will be significantly less than $\$ 80$. It is better to face a $1 / 100,000$ risk of mortality in twenty years than to face such a risk now.

If the issue is how much people now living will be willing to pay in twenty years to eliminate a risk of $1 / 100,000$, the resulting amount must be subject to the appropriate discount rate for money-and hence a VSL of $\$ 10$ million, if that is the appropriate amount in twenty years, must be discounted too. The reason has nothing to do with discounting life or health; it is that a sum of money in the future is worth less than the same sum today. Recall that any particular dollar amount in twenty years is worth some fraction of that figure now not for any exotic or theoretically contentious reason, but because the fraction can be invested and made to grow. ${ }^{63}$

\section{COUNTERARGUMENTS}

How might this argument be resisted? As we have noted, it is correct to say that national wealth tends to increase over time, and hence people will likely be wealthier in twenty years than they now are. Because they will be wealthier, they will demand more to be subject to statistical risks. For this reason, use of the current VSL to calculate monetary amounts in the future likely produces unjustifiably low numbers. ${ }^{64}$ But these are not points against discounting. They simply suggest

63 People also seem to have a "pure" time preference for money. See Revesz, 99 Colum $\mathrm{L}$ Rev at 958-59 (cited in note 8) (explaining the preference to have money now as opposed to later so that it can be invested or consumed). For purposes of our treatment here, it is not necessary to distinguish between time preference and investment value.

64 See Dora L. Costa and Matthew E. Kahn, The Rising Price of Nonmarket Goods, 93 Am Econ Rev Papers \& Proc 227, 229 table 1 (2003) (suggesting a likely current value of life of $\$ 12$ million, based on wage increases over time). In the context of arsenic regulation, the EPA also noted in its sensitivity analysis that the appropriate adjustment would increase the VSL from $\$ 6.1$ million to $\$ 6.7$ million. 66 Fed Reg at 7013 (cited in note 42) (reflecting an adjustment of the VSL for real income growth that occurred after the completion of the EPA's wage-risk studies). 
that the numbers that must be discounted are higher than regulators currently recognize. The proper analysis uses a multiplier for national income growth and any other relevant factors, and applies a discount rate from that point.

Similarly, it might be argued that agencies are on fragile ground in using labor market studies to estimate VSL. ${ }^{65}$ Perhaps workers, accepting a $\$ 60$ premium to face a risk of $1 / 100,000$, are insufficiently informed, are boundedly rational, or are subject to some form of coercion. Perhaps the proper premium is $\$ 70$, or $\$ 100$, or $\$ 200$. Perhaps the problem of insufficient information or bounded rationality is especially serious insofar as we are concerned with risks that will not materialize for a long time. Perhaps we cannot entirely trust either market evidence or contingent-valuation studies that generate numbers for risks that will not come to fruition for a decade or more. If so, we would have to rethink whatever numbers we have, but discounting itself would be unaffected. What would be used would be the proper monetary amounts rather than the improper ones. So long as any monetary valuation is used, discounting generally follows. To repeat: when discounting occurs, it is money that is being discounted, not the goods to which monetary amounts are being assigned.

A separate objection would stress that in the future technological, medical, and other changes will produce a range of improvements with respect to health, safety, and the environment. Harms that we now project, holding current practices constant, might well not materialize, simply because posterity will be in a position to prevent them. Perhaps climate change will produce less-serious harms than we imagine because adaptation will be possible, or because technology will be able to reduce warming. This objection is not implausible in itself, but it is not a claim about discounting. It is true that regulators who are projecting future harms should attempt to make an accurate projection, and accuracy requires an appreciation of technological innovation. But a "probabilistic discount rate,"

Note also that wealthier people might not merely be willing to spend more because they are wealthier; certain goods, such as environmental protection, might be especially appealing to wealthier people, whose preferences and tastes might change as a result of their relative wealth. See Revesz, 99 Colum L Rev at 963-64 (cited in note 8) (asserting that rising income over time can counteract the decrease in value of future enjoyment of utilities that discounting produces).

65 See Ackerman and Heinzerling, $150 \mathrm{U}$ Pa L Rev at 1562-70 (cited in note 15) (noting that cost-benefit analysis contains inherent flaws because it monetizes and devalues life in a way that is "at odds with [ ] common perspectives"). A general discussion can be found in Sunstein, 54 Duke $\mathbf{L}$ at $401-04$ (cited in note 57) (questioning reliance on VSL data in light of the fact that it is wide-ranging and outdated).

66 See Cowen and Parfit, Against the Social Discount Rate at 147 (cited in note 14) (arguing that predictions about the future should be discounted, as the farther off they are the more likely they are to be false). 
such innovation, should not be confused with the issues of discounting on which we are focusing here.

A more ambitious counterargument would suggest that the monetary values of human beings are not the proper basis for valuing some regulatory benefits. Consider, for example, the continued existence of an endangered species, or the lives of wild horses, tigers, pandas, and elephants. It is controversial (as it should be ${ }^{67}$ ) to say that endangered species and animals should be valued by aggregating people's willingness to pay to protect them. What might be sought is a more deliberative judgment, based on the exchange of reasons that can be offered on behalf of one or another outcome. ${ }^{68}$ Perhaps the underlying concern could be generalized to a range of benefits and amenities.

We should agree that there are many problems with the claim that all goods, including other living creatures, should be valued by aggregating private willingness to pay. But any method of valuation will necessarily include the explicit or implicit assignment of monetary values. Perhaps the assignment will or should come from democratic deliberation rather than through aggregating private willingness to pay, at least insofar as the Last Generation is considering its own future. But so long as any monetary assignment is made, discounting is generally appropriate, because no one doubts that it is appropriate to discount money.

\section{INTERGENERATIONAL EQUITY}

\section{A. The Basic Problem}

The argument thus far has not explored the question of intergenerational equity. Of course the amounts spent by future generations involve money, and at first glance that money must be discounted, simply because it is money. But critics are correct to say that discounting might contribute to serious problems involving intergenerational equity. ${ }^{70}$ The reason is that with discounting, a cost-benefit analysis can lead the current generation to impose extremely high burdens and

67 See Elizabeth Anderson, Value in Ethics and Economics 204-10 (Harvard 1993) (criticizing the valuation of endangered species and other environmental goods because it fails to capture how people value such goods outside the market context and because valuing the environment is not necessarily done out of self-interest or consumer demand).

68 See Amartya Sen, Rationality and Freedom 286-88 (Belknap 2002) (implying that people derive value from social goods even when they are not motivated by self-interest).

69 The status of (future) animals will, however, share some of the problems described in connection with future generations.

70 See Revesz, 99 Columbia L Rev at 996-1002 (cited in note 8) (suggesting that intergenerational discounting is unethical because pure time preferences mean that the current generation will use the majority of the available resources for its own welfare). 
costs on future generations-leading to a net welfare loss, a serious distributional problem, rights violations, or all three." To be sure, people might well have a pure time preference for money, choosing $\$ 100$ today over the financially equivalent sum in a year. ${ }^{72}$ But a pure time preference on the part of those now living cannot justify a discount rate with respect to harms faced by people not yet born. ${ }^{73}$

It is possible, of course, that even without much worrying about its obligations to posterity, current generations will contribute a great deal to their welfare. The course of human history, with astounding improvements in wealth, health, and longevity, makes it more than plausible to suggest that such contributions do occur over time. ${ }^{74}$ But there is no assurance that they will continue to occur, in general or for particular risks. ${ }^{75}$ Consider, for example, the problems of ozone depletion and climate change. The former problem once threatened, and the latter now threatens, to impose catastrophic risks on those who will come later. ${ }^{76}$ When the costs will be faced immediately, and the benefits enjoyed in the distant future, a cost-benefit analysis, based on discounting, can create genuine risks of both net welfare losses and distributional inequity."

71 See Portney and Weyant, Introduction at 6 (cited in note 13) (emphasizing the distributional problem and noting that "efficiency is hardly the only criterion that matters in policy analysis").

72 As noted, a pure time preference is challenged as irrational in Cowen and Parfit, Against the Social Discount Rate at 155 (cited in note 14). See also note 38 and accompanying text.

73 Id ("Pure time preference within a single life does not imply pure time preference across different lives.").

74 See Vernon Smith, Expert Panel Ranking, in Bjørn Lomborg, ed, Global Crises, Global Solutions 630,635 (Cambridge 2004) (stating that delay on global warming makes sense because of future gains in wealth, science, and knowledge); Thomas Schelling, Expert Panel Ranking, in Lomborg, ed, Global Crises 627, 627 (arguing that it makes no sense for current generations to pay to combat global warming because future generations will be "much richer" than current ones).

75 See Posner, Catastrophe at 151-53 (cited in note 9) (arguing that inaction is not the right course of action just because of uncertainty as to future capabilities and events); Robert C. Lind, Analysis for Intergenerational Decisionmaking, in Portney and Weyant, Discounting and Intergenerational Equity at 173,176 (cited in note 2) (arguing that there is no guarantee that current generations will contribute to future generations).

76 See Cass R. Sunstein, Montreal vs. Kyoto: A Tale of Two Protocols 30 Harv Envir L Rev (forthcoming 2007) (emphasizing intergenerational inequities that both problems yield because the chemicals and gases produced "stay in the atmosphere for an extremely long time").

77 William Baumol suggests that a low discount rate, or even a zero discount rate, might make sense in narrow circumstances, such as those in which the goal is to prevent environmental damage that is both irreversible and potentially catastrophic. See Baumol, $58 \mathrm{Am}$ Econ Rev at 801 (cited in note 9) (asserting that a high discount rate is appropriate in most situations, as "the future can be left to take care of itself," but reserving low discount rates for "irreversiblities"). In our view, this suggestion is best taken as an effort to protect future generations against unjustifiable losses as a result of the actions of the current generation. On this particular problem, see Cass R. Sunstein, Irreversible and Catastrophic, 91 Cornell L Rev 841, 894-96 (2006) (discussing how law and policy should handle potentially irreversible and catastrophic events -in particular how cost-benefit analyses should be adjusted in order to account for such events). 
It is not at all clear, however, that a refusal to discount is the best way of reducing those risks. On the contrary, any such refusal might well injure members of future generations. When the costs of regulation will be incurred in the distant future, and the benefits enjoyed immediately, discounting can be actually quite helpful to future generations, because it ensures current investments that redound to their benefit. ${ }^{78}$ And if present benefits will ultimately produce welfare gains for future generations, a refusal to discount can be quite harmful; most of the time, the future gains from the increased wealth of the present. ${ }^{79}$

It follows that the question of discounting should be separated from the question of obligations to future generations. It is not productive to collapse those two questions. If cost-benefit analysis with discounting imposes a serious loss on members of future generations, the current generation should be asked to fulfill whatever moral obligations it has. A refusal to discount is a crude and possibly even perverse way of doing that.

\section{B. Methuselah, Paretoville, and Beyond}

To see the relevant considerations, consider five problems. Of these, the fourth and fifth are most important, but they are best understood in light of those that precede them.

\section{Methuselah.}

Suppose that society consists of only one person, who, it turns out, will live for a great many years, even centuries. Let us call him Methuselah. Suppose that Methuselah will face a set of health risks (by hypothesis, none of them fatal) over time. Suppose that each risk of concern-those that involve a significant malady -is in the vicinity of $1 / 100$, and that Methuselah is willing to pay $\$ 30,000$ to eliminate each of these risks. If Methuselah is paying to reduce those risks now, there is no need to worry about discounting; the question is how much he is willing to pay to reduce risks that will be aced imminently or some time in the future. If Methuselah is assessing the present value of his future expenditures, it is fully appropriate for him to discount those

78 See Viscusi, Fatal Tradeoffs at 145 (cited in note 53) (noting that a high discount rate means a high level of expected future productivity, and therefore a higher future income level; if benefit values are adjusted appropriately, high discount rates should not dramatically reduce the attractiveness of policies that benefit the future).

79 We are putting to one side debates about the (perhaps doubtful) contributions of economic growth to individual well-being. For a readable overview, see Robert H. Frank, Luxury Fever: Money and Happiness in an Era of Excess 146-58 (Princeton 1999) ("[T]he conflict between individual and group [interests] is the single most important explanation of current consumption patterns."). 
expenditures, even if they will be for risk reductions. If a 1/100 risk will be faced in 20 years, it is worth not $\$ 30,000$, but $\$ 30,000$ discounted to present value. Methuselah can invest that discounted amount and watch it grow. ${ }^{80}$ Money is being discounted, not health-a restatement of our conclusion in Part II.

This conclusion might be questioned if Methuselah is seen as a series of selves extending over time and if an early self does not act as an appropriate agent for the later one. ${ }^{81}$ It is possible that Methuselah should be required to take steps to insure against serious harms in old age, especially if bounded rationality, including self-control problems, looms large. But if we indulge the not implausible assumption that Methuselah, of all people (!), is a good agent for his later self, discounting is fully appropriate.

\section{Paretoville.}

Suppose that everyone in a small town, Paretoville, faces a current risk of $1 / 100,000$, and that every resident of Paretoville, having the same tastes and the same amount of income and wealth, is willing to pay $\$ 50$, but no more, to eliminate that risk. (Suppose, too, that such residents have been adequately informed and are not suffering from any kind of bounded rationality.) The mayor of Paretoville takes this figure very seriously, and decides not to eliminate risks of $1 / 100,000$ if the cost of doing so is greater than $\$ 50$. Under the assumptions of adequate information and sufficient rationality, the mayor is reasonably using costbenefit analysis in deciding how to proceed, and there is no objection from the standpoint of equity. The reason is that every member of Paretoville pays, in full, for risk reduction, and people should not be required to pay more than they wish unless there is a problem of inadequate information, bounded rationality, or harms to third parties. ${ }^{83}$ In

80 By itself, this argument rejects Revesz's claims about the appropriate treatment of latent harms. See Revesz, 99 Colum L Rev at 984 (cited in note 8):

The reason for discounting in the case of latent harms is not that a regulator ... determines that life in the future is less than life in the present. Instead, discounting simply reflects the fact that the individual who is valuing her own life derives less utility from living a year in the future than in the present.

81 See Parfit, Reasons and Persons at 302-06 (cited in note 14) (suggesting that imagining different people throughout time as a series of "successive selves" helps in thinking about connectedness between generations).

82 See Sunstein, 54 Duke L J at 422-25 (cited in note 57) (arguing against forced exchanges of money for risk reduction by the government, as individuals should be permitted to make their own decisions regarding their welfare).

83 Id (highlighting the difference between this situation of equality and a situation where the poor would be made worse off by being forced to use their limited resources on an unwanted reduction in risk). 
some regulatory contexts, all three problems introduce serious complications, ${ }^{84}$ but we are assuming that they are absent in Paretoville.

For the citizens of Paretoville, the analysis of discounting is straightforward. If expenditures must be made now to reduce risks that will impose harm in the future, the mayor of Paretoville must ask about current willingness to pay to avoid such risks; in all likelihood, the figure will be less than $\$ 50$. If the expenditures must be made in the future, the relevant amounts should be discounted.

3. Dirtyville and Cleanville in Kaldorhicksiana.

Two towns, Dirtyville and Cleanville, are adjacent to one another in the large and somewhat messy state of Kaldorhicksiana. Dirtyville engages in polluting activity that produces $\$ 60$ in benefits to each of its 100,000 citizens. That activity creates a risk of $1 / 100,000$, faced by each of the 100,000 citizens of Cleanville. Each citizen of Cleanville is willing to pay $\$ 50$, but no more, to eliminate the risk of $1 / 100,000$ caused by Dirtyville's polluting activity. On cost-benefit grounds, the polluting activity should be allowed; its value is $\$ 6$ million, which is higher than its $\$ 5$ million cost.

But this problem is different from Problem 2 because there is a distributional issue: the citizens of Cleanville are uncompensated losers. If we were committed to economic efficiency, we would want the polluting activity to continue, but the distributional problem complicates matters. And the problem may be worse still. Because monetized figures rather than direct measurements of welfare are involved, it is possible that the activity actually creates a net welfare loss, with the citizens of Cleanville losing more, in welfare terms, than the citizens of Dirtyville gain. ${ }^{85}$ Suppose, for instance, that the citizens of Cleanville are relatively poor, and hence their willingness to pay only $\$ 50$ to eliminate a risk of $1 / 100,000$ is consistent with the conclusion that they are facing a huge welfare loss from their subjection to that risk. The relatively small amount each citizen is willing to pay- $\$ 50$-reflects the relative poverty of Cleanville, not a relatively small welfare loss. On plausible assumptions, the state of Kaldorhicksiana, containing these two towns, is not living up to its name, because the losers are not, in welfare terms, losing less than the winners gain.

84 Id (providing examples of such complications, including workers' compensation programs, where "nonunionized workers faced a dollar-for-dollar wage reduction, corresponding almost perfectly to the expected value of the benefits that they received").

85 See Matthew Adler and Eric A. Posner, Implementing Cost-Benefit Analysis When Preferences Are Distorted, 29 J Legal Stud 1105, 1122-24 (2000) (discussing how measurement in money, rather than direct welfare, points to a problem with the use of cost-benefit analysis). 
The welfare question could be tested, and the problem could be made analytically equivalent to Problem 2 , if the citizens of Dirtyville could be forced to compensate those of Cleanville through law or some process of bargaining. But let us suppose that this is not feasible. In that event, we cannot be sure whether the efficient solution is also the solution that promotes social welfare. An additional question, a familiar one in regulatory policy, is whether there should be some kind of equitable or distributional barrier to the use of cost-benefit balancing. ${ }^{86}$ If the citizens of Dirtyville are wealthy, and those of Cleanville are poor, the barrier might well be justified, at least if there is no mechanism by which the citizens of Cleanville can capture some of the benefits of the activity.

Does this example seem fanciful? In fact many air pollution problems correspond to the tale of Dirtyville and Cleanville. As we shall see, the problem of climate change has a similar feature insofar as wealthy nations are imposing risks on poor ones-risks for whose prevention poor citizens in poor nations are not willing to pay all that much, even when they are gravely threatened.

\section{Presentville and Futureville.}

Presentville engages in polluting activity that produces $\$ 60$ in benefits to each of its 100,000 citizens. But the polluting activity does not harm citizens of Presentville or any other current place. Instead, it harms members of future generations. More particularly, the activity creates a risk that will materialize in 100 years, in the town of Futureville-which, as it happens, is Presentville, a century from now and much more populous. In that time, the one million citizens of Futureville will face a death risk of $1 / 10,000-$ meaning that 100 people are expected to die. If the lives of the people of Futureville are valued at $\$ 8$ million each, it is clear that the polluting activity should stop, because $\$ 800$ million is far greater than $\$ 6$ million. But if money is discounted at an annual rate of 7 percent, each of their lives is worth only $\$ 581$, and hence the polluting activity should continue, because $\$ 6$ million is far greater than $\$ 58,100$.

But on what premises does it make sense to refuse a $\$ 6$ million (current) expenditure to save 100 future lives? If all the people of Presentville and Futureville were treated as a single person extending over time, then the case would be similar to Methuselah's, and discounting would be appropriate. In that case, the various people would

86 See Portney and Weyant, Introduction at 6 (cited in note 13) (arguing that even if a program passes a cost-benefit analysis it may nonetheless be objected to on distributional grounds, as it may be efficient, yet still benefit only "the five richest families in the country"). 
amount to just one person who could invest the relevant resources and use them later. (Also, no one would die, because we're talking about Methuselah.) It is tempting to suppose that if there were an intergenerational negotiation between the people of Presentville and the people of Futureville, discounting would be part of a mutually beneficial trade. ${ }^{87}$ Here is the reason: the people of Presentville could agree not to squander or to consume the benefits they receive, but instead to invest a relevant sum and offer that amount to the people of Futureville, making them better off on balance. Those who emphasize the opportunity costs of investments as a reason for discounting, including $\mathrm{OMB}$, implicitly appeal to the idea that future generations will in fact benefit from the investments that current generations make. ${ }^{8 g}$ Hence discounting might be seen as a part of a (hypothetical) mutually beneficial intergenerational negotiation.

But there are two problems with relying on that idea. The first is conceptual: what is the set of background entitlements against which this purely hypothetical negotiation is occurring? At first glance, the people of Presentville are literally dictators. They can decide to consume all existing resources, to ruin the environment, to impoverish posterity, even to remain childless and not create later generations at all. In the (hypothetical) negotiating process, are the people of Presentville permitted to threaten the (hypothetical) people of Futureville with nonexistence? If so, how much will Futureville be able to extract? If not, is this because hypothetical people have some entitlement to be permitted to exist? (How many of them?) And if Presentville merely threatens Futureville with impoverishment and desperation, the people of Futureville will be in a singularly weak position to extract protection against (say) individual risks of death of $1 / 100,000$.

In short, the idea of a mutually beneficial deal raises serious conceptual difficulties. At the very least, it is necessary to identify some entitlements on the part of both Presentville and Futureville, setting

87 See Dexter Samida and David A. Weisbach, Paretian Intergenerational Discounting, 74 U Chi L Rev 145, 153 (2007):

An alternative version of equality would give the first generation approximately 80 units [out of 100 total] and the rest to the second generation (giving each one an endowment of that amount in the first year of its life). When the second generation's endowment of 20 is invested at 3 percent for the first 50 years, it will grow to about 80 units in year 51, generating an equal division of the resources.

See also Lind, Analysis for Intergenerational Decisionmaking at 176-77 (cited in note 75) ("In theory, this could be done in a world with overlapping generations. In practice, this is virtually impossible, in part because of the problem of getting and enforcing the commitment of intervening generations to carry out this intergenerational transfer.").

88 See, for example, Lind, Analysis for Intergenerational Decisionmaking at 176-77 (cited in note 75). 
the background against which they might bargain. To be plausible, any such specification will inevitably have to depend on an independent normative account of some kind, and that independent account, rather than a notion of intergenerational bargaining as such, will be doing the crucial work. ${ }^{89}$

The second problem is pragmatic. Suppose, as is plausible, that there is no mechanism to ensure that any mutually beneficial bargain will be enforceable; the citizens of Presentville might simply consume their resources instead. ${ }^{\text {on }}$ To be sure, the problem could be solved with compensation, and the discounted value of the 100 future deaths should be used if Futureville will sufficiently benefit from the investment of that sum (by, for example, producing significant decreases in premature deaths). If so, the case would be quite similar to Problem 2 (back to Paretoville). But as we have noted, there is no assurance that this will be the case.

It should be clear that Presentville is neither Methuselah nor Paretoville. But with cost-benefit analysis with discounting, the problem of Presentville and Futureville has many features in common with that of Cleanville and Dirtyville. In the case of Kaldorhicksiana, the use of cost-benefit analysis can create distributional problems, and it can even lead to an aggregate welfare loss; in the case of Presentville and Futureville, cost-benefit analysis with discounting may create those same problems. But the case of Presentville and Futureville nonetheless raises distinct questions: What does the present owe the future? Is the present obliged to compensate the future for the injuries it causes? What does the idea of "compensation" mean in this con-

89 Hence John Rawls rejects the idea of intergenerational bargaining in favor of a just savings principle. See John Rawls, Political Liberalism 287-88 (Columbia 1993) (asserting that social contracts "are bound to be substantially affected by contingencies and accidents"). For further discussion see note 103.

90 See Portney and Weyant, Introduction at 6 (cited in note 13) ("Even if it is efficient to reject a climate protection program, ... one might reasonably object to this decision on distributional grounds, especially if one is dubious that [ ] compensation will actually be available to future generations."); Lind, Analysis for Intergenerational Decisionmaking at 176-77 (cited in note 75) ("We are so used to assuming the ability to transfer resources over time we sometimes forget that if we can't, then it's not appropriate to convert all flows to a present value."); Cowen and Parfit, Against the Social Discount Rate at 151-52 (cited in note 14) (arguing that it is a mistake to think benefits will be reinvested rather than simply consumed). Donohue defends discounting on the ground that it "is appropriate in that, if invested, our resources are expected to grow at [the stated] rate, so that if we forego spending and invest the money instead, we can save more lives in the future with the amount foregone today." Donohue, 108 Yale L J at 1905 (cited in note 13) (rejecting the notion that discounting reflects a lower valuation of future lives in a moral or ethical sense). The problem with this argument is that it assumes that Problem 4 is the same as Problem 1-that society is a kind of giant Methuselah, which it clearly is not.

91 See Lind, Analysis for Intergenerational Decisionmaking at 176-77 (cited in note 75). 
text? We will shortly return to these questions and their connection to the practice of discounting.

\section{Reality.}

Turn now to a more realistic example, involving climate change." Suppose, as is plausible, that the primary victims of climate change will include poor people in India and Africa. Suppose that the planners concerned with climate change decide what to do by engaging in costbenefit analysis and discounting the victims' costs to present value. If so, such victims will not be much helped, because no one is planning to invest the discounted sum to create a fund to compensate them in the future. The result of relying solely on cost-benefit analysis with discounting may be serious welfare losses, distributional unfairness, or both. To be sure, technological innovations might mean that what we see as likely deaths, or many of them, will end up as mere illnesses (and perhaps minor illnesses at that). But this possibility does not justify discounting. It is instead an effort to deny that the anticipated harms will be as large as we project. If that number is inflated, then of course the analysis must change.

It is also true that future generations are likely to be wealthier than our own, and hence it might not make much sense for the relatively poor present to transfer resources to the relatively rich future. ${ }^{94}$ This would be a perverse form of redistribution. If future generations can be expected to be richer, that point must be part of the analysis of what equity requires. And if future generations can be expected to be richer, their anticipated wealth is produced by some combination of the efforts, investments, and altruism of their predecessors-a point that compounds the concern about perverse redistribution.

But even here, there are complications. Suppose, for example, that a relatively poor community is gaining $\$ 6$ million as a result of activity that will cause 100 deaths in a relatively wealthy community. Is

92 See Posner, Catastrophe at 151-52 (cited in note 9) (considering how, through discounting, an investment in climate protection may not seem efficient, and countering that there is no other realistic alternative because creating and maintaining a fund for the compensation of future global warming victims is highly unlikely).

93 See William D. Nordhaus and Joseph Boyer, Warming the World: Economic Models of Global Warming 91 (MIT 2000) (showing especially large losses in India and Africa). See also generally J. Timmons Roberts and Bradley C. Parks, Climate of Injustice: Global Inequality, North-South Politics, and Climate Policy (MIT 2006) (exploring normative and empirical issues raised by the distributional effects of climate change, with its severe impact on poor nations); Stern Review at 104-05 (cited in note 29).

94 See Schelling, Expert Panel Ranking at 627 (cited in note 74) ("One must deduct the growth rate from the discount rate, since it is essential to assume overall growth in per capita income (global GDP)."). 
the activity justified merely because poorer people are obtaining the benefit, which by hypothesis is much smaller than the cost? That claim would be exceedingly difficult to defend. The most general pointsuggested by the problem of Presentville and Futureville-is that costbenefit analysis with discounting can indeed produce serious problems across generations, including a net welfare loss and distributional unfairness. In the case of climate change, these problems need to be considered, and they suggest that we might well reject the path suggested by cost-benefit analysis with a standard discount rate.

Responding to concerns of this sort, Thomas Schelling argues that "[g]reenhouse gas abatement is a foreign aid program, not a savinginvestment problem of the familiar kind." For long-term problems, it might be thought that the question is whether the current generation should provide "foreign aid" to posterity. And to the extent that posterity is likely to be wealthier than we are, ${ }^{96}$ there is a serious question whether such aid should be provided. As Schelling suggests, citizens of the developed world are not now willing to make especially significant sacrifices to help people in poor nations; it would seem extremely unlikely that in the context of climate change, such citizens would be willing to make significant sacrifices to assist people in those same nations in the distant and probably less-poor future."

But Schelling's analogy has serious problems. In our example, Futureville is not merely a foreign country. It consists to a large extent of Presentville's own descendents, and the risks they face are a direct result of Presentville's own actions-both plausible reasons to think that Futureville might have special obligations towards Presentville. The problem of climate change is closely analogous. The idea of "foreign aid" is a singularly poor fit for that problem, in which environmental and health risks in some Futurevilles are a product of actions undertaken knowingly (and perhaps negligently) by some Presentvilles. In that event, the present might well be seen to have committed a kind of tort, and the claim for compensation is hardly a claim for some kind of subsidy, or "aid."

To give a stark example, imagine that present generations plant a bomb that will explode in two centuries. Is this a violation of the obli-

95 Thomas Schelling, Intergenerational Discounting, in Portney and Weyant, Discounting and Intergenerational Equity 99,100 (cited in note 2).

96 Id at 100-01 (asserting that discounting is appropriate because it represents a choice to help those who are relatively poorer, the current generation, rather than those who will be relatively richer, future generations).

97 Id at 101 (maintaining that it is inappropriate to consider investments in environmental protection as an issue of "investing now to reap future benefits," as those who will benefit will likely live in a different part of the world and be relatively richer than those doing the investing).

98 See Roberts and Parks, Climate of Injustice at 1-2 (cited in note 93). 
gation to provide "foreign aid"? Environmental problems are rarely bombs, for they are usually not created with malice or with destructive goals; but if they result from activities that are projected to create risks, they must be analyzed in the general terms of tort law. This point has important implications for climate change, because the risks, faced above all by poor nations, are a result of actions from which wealthier nations have benefited.

\section{Not Discounting as a Crude Response to the Intergenerational Problem}

1. Discounting and moral obligations to posterity.

Suppose that the present generation believes that it has moral obligations to its successors, either because those successors will be our children's children, or because whoever they are, they will be injured by our actions. The point that we seek to emphasize here is that refusing to discount is not a good way of fulfilling these obligations. ${ }^{99}$ Indeed, any such refusal might well hurt posterity. The moral obligation is best discharged not by a zero discount rate, but by asking the current generation to do what it is morally obliged to do.

A refusal to discount, often justified as a way of assisting the future, ${ }^{100}$ is a singularly crude way of attempting to fulfill our obligations to future generations. There are two problems. The first is that if the refusal to discount will result in the postponement of protective programs, environmental and otherwise, the future is to that extent hurt rather than helped. ${ }^{101}$ The second is that if the consequence of dis-

99 See Samida and Weisbach, 74 U Chi L Rev at 154 (cited in note 87) ("[W]e care about equality of well-being while those arguing against discounting are arguing for an equal division of current resources, which will inevitably lead to an inequality in well-being."). See also Cowen and Parfit, Against the Social Discount Rate at 158-59 (cited in note 14) (suggesting that while remoteness in time is not a reason to care less about social harms, it might make sense to take account of the possibility that "it would be cheaper now to ensure compensation"). William Nordhaus provides a powerful argument against responding to the ethically unacceptable consequences of cost-benefit analysis by altering discount rates, on the view that "[a]d hoc manipulation of discount rates is a very poor substitute for policies that focus directly on the ultimate objective." William D. Nordhaus, Discounting and Public Policies That Affect the Distant Future at 158 (cited in note 50) (contending that "there is no simple formula for modifying discount rates that incorporates long-term objectives in an efficient manner").

100 See Ackerman and Heinzerling, $150 \mathrm{U}$ Pa L Rev at 1570-71 (cited in note 15) (asserting that discounting does not make sense in environmental law, an area of law that is distinctive because of its focus on the future); Revesz, 99 Colum L Rev at 987-1007 (cited in note 8) (arguing against intergenerational discounting, as it could produce a world where "practically no current expenditure for the benefit of relatively distant generations could be justified within a cost-benefit framework").

101 See Keeler and Cretin, $29 \mathrm{Mgmt}$ Sci at 303-04 (cited in note 24) ("For any attractive program, there is always a superior delayed program that should be funded first. The result is that no program with a finite starting date can be selected."). 
counting is to reduce investments, economic and otherwise, that will lead to long-term prosperity, then discounting is hardly helpful to future generations, which greatly benefit from economic growth. ${ }^{102}$ It follows that the moral obligations of current generations should be uncoupled from the question of discounting, because neither discounting nor refusing to discount is an effective way of ensuring that those obligations are fulfilled. The moral issues should be investigated directly, and they should be disentangled from the practice of discounting.

\section{Theory.}

We have argued that future generations might well have a legitimate complaint if current generations follow the path indicated by cost-benefit analysis with discounting. But what kind of complaint do they have? To answer that question, it is necessary to say something about the nature of intergenerational equity.

As we have suggested, it is tempting to think of ethical obligations in compensatory terms, as in the idea that ethical obligations are satisfied if the present can make it worthwhile for future generations to run the risks to which it subjects them. But this idea turns out to be a false start because it is hard to know what the idea of compensation means in this context. Must the present compensate the future for each particular risk? That conclusion would be implausible. Surely it would be acceptable to impose a risk of $1 / 100,000$ on 10 million future people if the very step that imposes that risk also eliminates a $1 / 1,000$ risk that would be faced by 800 million future people (including the 10 million future people subjected to a new $1 / 100,000$ risk of death). At first glance, then, the goal should be to produce an overall "risk package" for which adequate compensation has been paid. But to what, exactly, is this overall risk package being compared? To a situation in which future generations face extreme poverty and catastrophic climate change? To a situation in which future generations do not exist at all? Do members of future generations have rights to exist? These questions are closely connected with the difficulty of specifying the background entitlements against which any hypothetical bargaining occurs. ${ }^{103}$

102 Complications are outlined in Frank, Luxury Fever at 72-73 (cited in note 79) (noting that economic growth does not increase self-reported life satisfaction).

103 Note too that Rawls's "just savings" principle would be satisfied by less than full compensation. The reason is that it is possible to imagine, without full compensation for risks, a system of savings that will bring "about the full realization of just institutions and the equal liberties," with particular reference to the "standpoint of the least advantaged of each generation." Rawls, Political Liberalism at 287-88 (cited in note 89) ("[A]ny benchmark of comparison between the relative advantages of citizens must be founded on their present relationships and the way in which social institutions work now, and not on how the actual ... historical sequence of transactions extending backward over generations has improved (or would improve) everyone's 
In short, it is necessary to identify the baseline against which any "compensation" must be paid, and the real work is being done by that baseline, not by the idea of compensation. The baseline must come from a more general account of the ethical obligations owed by the present to the future ${ }^{104}$ - and hence we are not speaking of compensation at all. What might that account require? Some people believe that current generations are obliged not to make the environment worse than it is today. ${ }^{105}$ On this view, current generations are environmental trustees. As such, they must follow a kind of environmental nondegradation principle. But there is a problem with this position, which is its selective focus on environmental quality. Suppose that the current generation sacrifices a remote island, but that as a direct result of that action, it is able to confer significant economic, medical, and other benefits on posterity, giving them healthier, longer, and better lives. Is it so clear that the sacrifice is morally unacceptable?

John Rawls emphasizes a more promising approach, embodied in a "just savings" principle, to be chosen by people behind a veil of ignorance in which "they do not know to which generation they belong or, what comes to the same thing, the stage of civilization of their society." The key point, for Rawls, is the extension of the device of the veil of ignorance to the intergenerational question. Rawls also contends that his conception of justice as fairness ought to inform choices behind the

circumstances."). Indeed, it is possible to imagine situations in which full compensation might well be too demanding. Suppose, for example, that the result of full compensation would be to impoverish the most disadvantaged members of the current generation, in order to ensure compensation to the already-wealthy members of future generations. Current generations might, in principle, be able to claim that full compensation is not necessary when the distributive consequences are perverse. In fact, this claim raises some causal and even conceptual difficulties: If future generations are significantly wealthier than past generations, their wealth is partly attributable to the actions and omissions of their predecessors. Once the causal chains have been sorted out, we might well conclude that adequate compensation has been paid for any risks, taken not separately but as a whole.

104 For an influential view, see John Rawls, $A$ Theory of Justice 284-93 (Belknap revised ed 1999) ("The present generation cannot do as it pleases but is bound by the principles that would be chosen in the original position to define justice between persons at different moments of time."). For a helpful overview, see Lukas Meyer, Intergenerational Justice, in Edward N. Zalta, ed, The Stanford Encyclopedia of Philosophy, online at http://plato.stanford.edu/archives/ sum2003/entries/justice-intergenerational/ (visited Jan 23, 2007) ("The special features of our relations to (remote) future people-especially the lack of particular knowledge, the impossibility of cooperation, and the permanent asymmetry of influence-do not stand in the way of attributing rights to them that ground corresponding duties owed by us.").

105 See Edith Brown Weiss, Intergenerational Equity: A Legal Framework for Global Environmental Change, in Edith Brown Weiss, ed, Environmental Change and International Law: New Challenges and Dimensions 385, 390-93 (United Nations University 1991) (discussing several international agreements that "have contained language indicating either a concern for sustainable use of the environment or a concern for future generations").

106 Rawls, A Theory of Justice at 254 (cited in note 104) (contending that a veil of ignorance is the only way to truly consider what a fair exchange would look like). 
veil. What is required, on his view, is a system of savings that will bring about "the full realization of just institutions and the equal liberties,",in with close attention to the "standpoint of the least advantaged of each generation." ${ }^{108}$ Under this approach, cost-benefit analysis with discounting will create serious problems from the standpoint of justice if it leads to decisions that (for example) impose especially grave hardships on the most disadvantaged members of future societies. The proper response would be to take steps to conform to the just savings principle.

On this view, for example, it would be unacceptable to refuse to take steps to protect against climate change if the refusal would lead to a violation of equal liberties, or if it meant that the least advantaged members of future generations would suffer extreme hardship, well beyond that of the least advantaged members of the current generation. On the other hand, the current generation would not be required to take protective measures that would produce hardship for its least advantaged members, if those least advantaged members are more disadvantaged than would be any other group in any future generation, even in the absence of those protective measures. (Suppose, for example, that serious efforts to reduce greenhouse gases would be extremely expensive, and that the expense would have to be borne in part by the most disadvantaged members of current generations.) And indeed, some debates over climate change devote attention to issues of exactly this sort."

In a later treatment, Rawls suggests that it is unhelpful to "imagine a (hypothetical and nonhistorical) direct agreement between all generations." ${ }^{110}$ Instead the parties, behind the veil of ignorance, might be "required to agree to a savings principle subject to the further condition that they must want all previous generations to have followed it." "111 This savings principle has the advantage of treating all generations the same, through a form of intergenerational neutrality that protects against the dual problems of impoverishing the present and impoverishing the future. On Rawls's approach, policies that harmed the most disadvantaged members of current generations for the sake of the future would likely be disfavored, and the question would be

107 Id at 257 (declining to extend this to the proposition that justice requires that "early generations save so that later ones are simply more wealthy").

108 Id at 258.

109 See, for example, Indur Goklany, The Precautionary Principle 85-87 (Cato Institute 2002) (discussing how the "precautionary principle" counsels against assuming an overly aggressive strategy in combating greenhouse gases, as this could harm the current generation and thereby "retard increases in global wealth").

110 Rawls, Political Liberalism at 274 (cited in note 89) (discussing the need for "just savings" between generations, as "society is a system of cooperation between generations over time").

111 Id. 
whether those policies were necessary to protect the most disadvantaged members of future generations from still greater harm (as, on one view, is the case for emissions of greenhouse gases ${ }^{112}$ ).

Rawls's own approach is not utilitarian or welfarist, but it would be easy to adapt the idea of a veil of ignorance, and the notion of intergenerational neutrality, ${ }^{113}$ for welfarist purposes. From the welfarist point of view, the goal should be to maximize welfare over time; welfarists would require current generations to give members of future generations the same moral weight that they give to existing people. Hence the current generation violates its ethical responsibilities if it engages in projects that lead to net welfare losses, measured after including the interests of all generations (where interests themselves are given equal weight). Of course this approach raises many puzzles; for example, do we focus on the average welfare of those in future generations, or do we focus on aggregate welfare, in which case large populations are better by virtue of their size?

However such puzzles are resolved, we believe that the idea of a veil of ignorance is appealing, and that it points in the right directions. But the aim here is to sketch rather than to solve the problem of intergenerational equity. Behind the veil, discounting would often be chosen because it would help future generations as well as the present one. When discounting would not be chosen, it is because it would have a harmful effect on the most disadvantaged people (on Rawls's difference principle), or because it would reduce overall welfare (on a welfarist approach). But it would be much better to focus directly on intergenerational equity, and to explore how present generations should fulfill their obligations independently of the question of discounting. While cost-benefit analysis with discounting can violate principles of intergenerational equity, refusing to discount is not the right way to satisfy those principles. Whatever the proper approach to intergenerational equity, the debate over that issue should be separated from the debate over discounting, and the former debate should be engaged directly.

\section{Conclusions.}

Some simple conclusions follow from this analysis. Cost-benefit analysis with discounting can produce serious distributional problems

112 See Posner, Catastrophe at 151-53 (cited in note 9) (highlighting the example of greenhouse gases, which has an increased annual cost over time).

113 On intergenerational neutrality, see Stern Review at 31 (cited in note 29) ("II]f a future generation will be present, we suppose that it has the same claim on our ethical attention as the current one."). See also generally Cass R. Sunstein, Worst-Case Scenarios (forthcoming Harvard 2007). 
and can easily lead to a net welfare loss. The proper response is to take steps to ensure that present generations do not violate their obligations to posterity. On an optimistic view, no special steps are necessary. Some combination of market forces and ordinary altruism tends to ensure that those who come later are, in all relevant respects, significantly better off than those who came before. ${ }^{114}$

But perhaps the optimistic view is unrealistic for some problems, such as climate change. Suppose that climate change imposes truly catastrophic losses on the world as a whole, or at least on the most vulnerable members of the most vulnerable nations. ${ }^{115}$ And even if the losses from climate change are not catastrophic, it would be surprising if the gains from refusing to spend money on greenhouse gas emissions will turn out to be used for the protection of those who are most likely to suffer from greenhouse gas emissions. Under plausible assumptions, the current generation should take self-conscious steps to protect its successors from the effects of climate change, no less than from the effects of ozone depletion. Our goal is not to specify the mechanisms by which the current generation fulfills that obligation, but to suggest that whether or not the optimistic view is right, a refusal to discount is not the appropriate response to the risk of intergenerational inequity.

\section{A Note on Sustainable Development}

In recent years, a great deal of attention has been devoted to the topic of "sustainable development," an idea that has considerable force in international law. ${ }^{116}$ Unfortunately, the idea of sustainability remains poorly defined. An influential report suggests that development is sustainable if it "meets the needs of the present without compromising the ability of future generations to meet their own needs"117

114 See Shelling, Expert Panel Ranking at 627 (cited in note 74) ("Future generations will be much richer than current ones, and it thus makes no sense to make current generations 'pay' for the problems of future generations."); Schelling, Intergenerational Discounting at 101 (cited in note 95) (arguing that, for this reason, investments for the benefit of the future must be considered as taking something from the poor to give to the rich).

115 See Stern Review at ii-viii, 57, 62-84 (cited in note 29); Posner, Catastrophe at 43-58 (cited in note 9).

116 See generally Alan Oxley, Environmental Protection and the WTO, in Julian Morris, ed, Sustainable Development 123 (Profile Books 2002) (discussing the potential impact of multilateral environmental agreements on World Trade Organization rules); Revesz, 99 Colum L Rev at 1009-14 (cited in note 8) (assessing sustainable development and its use in international agreements). See generally Sylvie Faucheux, David Pearce, and John L. Proops, Introduction, in Faucheux, Pearce, and Proops, Models of Sustainable Development at 1, 3-16 (cited in note 51) (discussing four models of sustainable development that have implications for international policy).

117 See World Commission on Environment and Development, Our Common Future 43 (Oxford 1987) (emphasizing the two key concepts within sustainable development: needs, particularly those of the poor, and limitations on the environment's ability to meet those needs). 
-a formulation that is vaguer than, but not so far from, Rawls's just savings principle. Robert Solow defines sustainability to require each generation to have the capacity to attain the same levels of welfare as those that preceded it. ${ }^{118}$ For the environmental context, this definition means that nonrenewable resources must be used so as not to make it impossible for future generations to acquire the same standard of living. ${ }^{119}$ Focusing specifically on the environment, Edith Brown Weiss argues that each generation has a duty not to make the environmental quality of the planet worse and also to preserve the essential options available to future generations. ${ }^{120}$

These specifications are contentious, for reasons that should be clear from the discussion thus far. But if the idea of sustainable development is designed to require present generations to pay close attention to the interests of those who will follow, it points in the right directions and may have considerable practical importance. Of course most people are willing to sacrifice their own well-being for the benefit of their children, and as we have noted, the arc of human history suggests that the standard of living increases over time in any case. But for some goods, including some environmental amenities, longterm losses are possible unless steps are taken to avoid them; climate change in particular threatens to impose large-scale risks on posterity. ${ }^{121}$ The idea of sustainable development can be seen as a reminder of the moral obligations of the present.

To the extent that the idea of sustainable development is meant to require a specific policy of preserving environmental goods, it offers a useful suggestion that current actions can produce short-run economic benefits while also creating long-term environmental problems. The suggestion is especially important in the face of potentially irre-

118 Robert Solow, An Almost Practical Step toward Sustainability, 19 Resources Policy 162, 168 (1993) (arguing that "sustainability is not always compatible with discounting the well-being of future generations if there is no continuing technological progress").

119 Id at 163 ("If 'sustainability' is anything more than a slogan or expression of emotion, it must amount to an injunction to preserve productive capacity for the indefinite future.").

120 Weiss, Intergenerational Equity at 385 (cited in note 105) (asserting that fulfilling the needs of the present generation efficiently is not enough to ensure equity across generations). Brown's account, like Solow's, goes well beyond what is required by Rawls's just savings principle. On the relevance of options, see Sunstein, 91 Cornell L Rev at 855-68 (cited in note 77) ("When regulators are dealing with an irreversible loss, and when they are uncertain about the timing and likelihood of that loss, they should be willing to pay a sum-the option value - to maintain flexibility for the future.").

121 See Stern Review at 56-167 (cited in note 29) (outlining effects of unchecked climate change); Posner, Catastrophe at 151-52 (cited in note 9) (stating that global warming will have potentially drastic consequences if no action is taken to abate it); Nordhaus and Boyer, Warming the World at 71 (cited in note 93) (asserting that catastrophic risks resulting from global warming have not been adequately studied and advocating willingness to pay as a measure of the value of preventing future climate change). 
versible environmental change. ${ }^{12}$ But environmental protection can burden the future too, especially if it is extremely costly, and there is no abstract reason to believe that preserving a particular environmental amenity (a forest, a lake) is always better for posterity than other investments that do not involve the environment in particular (expenditures on basic research, reductions in national debt). The appropriate conclusion is that an emphasis on sustainable development must be taken as a placeholder for a set of conclusions, requiring specification and independent justification, about what intergenerational equity requires.

\section{E. Implications}

What are the implications for reviewing courts and for regulatory practice? The question of judicial review is the easiest to handle. Courts are correct to require some kind of rationale for any particular discount rate (including a discount rate of zero). ${ }^{123}$ An implausibly high discount rate (say, 8 percent) would have to be explained, as would an implausibly low one (say, 0.2 percent). But the great complexity of the underlying issues, and the continued existence of reasonable disagreement, argue for a cautious judicial role, especially because of the risk that judicial invalidations will simply stall desirable regulation. ${ }^{124}$ Of course extreme cases can be imagined. ${ }^{125}$ Suppose that an agency refuses to discount the monetary value of health and safety benefits and that future generations are not involved. If so, it would be reasonable to rule that the agency's refusal is arbitrary, and perhaps any re-

122 See Sunstein, 91 Cornell L Rev at 855-62 (cited in note 77) (advocating paying a premium to maintain flexibility for being able to prevent irreversible environmental harm in the future); Posner, Catastrophe at 162 (cited in note 9) (discussing how irreversibilities, such as global warming, will require more resources to control in the future than in the present); Kenneth Arrow, Discounting, Morality, and Gaming, in Portney and Weyant, eds, Discounting and Intergenerational Equity 13, 17-20 (cited in note 2) (exploring the idea of irreversible investments, which "yield benefits to the distant future," yet "either cannot be plundered by intervening generations or will yield relatively little if they do try to interfere").

123 See Northern California Power Agency v FERC, 37 F3d 1517, 1522-23 (DC Cir 1994) (concluding that the Federal Energy Regulatory Commission's choice to apply a uniform 15 percent discount rate to all applications for new licenses for hydroelectric projects in California was proper); Natural Resources Defense Council v Herrington, 768 F2d 1355, 1410-14 (DC Cir 1985) (rejecting the Department of Energy's choice of a 10 percent discount rate in developing standards because the rate was "fatally unexplained").

124 See Jerry Mashaw and David Harfst, The Struggle For Auto Safety 5, 246 (Belknap 1990) (arguing that judicial regulation should be delayed until the enforcement stage, because this "limits dysfunctional incentives to procrastinate and to litigate, places decision making in the hands of the best-informed parties,... and limits the disruptive effects of judicial remedies").

125 The cost-benefit analysis for arsenic is an example. See 66 Fed Reg at 6976, 7012 (cited in note 42) (discussing the monetized value of benefits resulting from reducing arsenic in drinking water). 
sulting regulation should be struck down if the refusal to discount is responsible for its content. Or suppose that an agency paid no attention to the interests of those after 2050, or that it adopted a discount rate of 10 percent. But across a wide range of agency choices, judicial deference is the best general orientation.

Our discussion provides considerable support for OMB's general posture of requiring the same discount rate for all costs and benefits. ${ }^{126}$ It does so not on OMB's unruly and complex rationale, ${ }^{127}$ but on the ground that for latent harms, what is being discounted is money and not risks to life and health as such. To the extent that regulations will mostly affect currently living people, a uniform discount rate is fully appropriate. Unfortunately, agencies have not always followed OMB's guidance with respect to discount rates. ${ }^{128}$ On this issue, at least, they ought to do so.

The analysis must be more complicated when planners are affecting the welfare of future generations-as, for example, in the assessments of values associated with protection against climate change or depletion of the ozone layer. Some people argue in favor of, or use, a uniform discount rate for such values. ${ }^{129}$ Nothing said here demonstrates that a uniform discount rate is always wrong; and in the context of ozone depletion, cost-benefit analysis with discounting justified extremely aggressive measures to protect future generations. ${ }^{130}$ But we

126 See OMB, Circular A-4 at 33-34 (cited in note 3) (setting out a discount rate of 7 percent for regulations whose main effects are "to displace or alter the use of capital in the private sector," and a discount rate of 3 percent for regulations "primarily and directly affecting private consumption") We do not attempt here to endorse any particular discount rate, and certainly not to suggest that the 7 percent figure, which seems badly outmoded, is an appropriate one. See note 125 .

127 See id ("[T]he analytically preferred method of handling temporal differences between benefits and costs is to adjust all benefits and costs to reflect their value in equivalent units of consumption and to discount them at the rate consumers and savers would normally use in discounting future consumption benefits.").

128 See Morrison, Comment, 65 U Chi L Rev at 1366-67 (cited in note 6) (demonstrating that different agencies employ a variety of discount rates). Again, we have not attempted to identify the appropriate discount rate, and hence have not taken a position on the two options suggested by OMB: 7 percent and 3 percent. The former figure is, however, far higher than the current return on risk-neutral investments, and for this reason it is not easy to defend.

129 See, for example, Nordhaus and Boyer, Warming the World at 112 (cited in note 93) (stressing that the discount rate should be the same across regions and temporally, but not specifying the appropriate rate).

130 See Sunstein, 30 Harv Envir L Rev (cited in note 76) (arguing that the different costbenefit assessments done for the Montreal and Kyoto Protocols explain why the Montreal Protocol has been successful, while the Kyoto Protocol has not); Stephen J. DeCanio, Economic Analysis, Environmental Policy, and Intergenerational Justice in the Reagan Administration: The Case of the Montreal Protocol, in 3 International Environmental Agreements: Politics, Law and Economics 299, 308-13 (2003) (detailing how the Reagan Administration and the framers of the Montreal Protocol were able to use economic analysis, combined with a principle of intergenerational neutrality, to bolster investment in ozone layer protection). 
have emphasized that for such problems as climate change, costbenefit analysis with the usual discount rate can produce both welfare losses and serious unfairness. ${ }^{131}$ In this context, social planners should not base their decisions solely on such analysis with discounting; the result of such analysis may be badly wrong. Any judgments about appropriate regulations must be accompanied by steps fulfilling the present generation's moral obligations to the future.

The tasks of conducting cost-benefit analysis for climate change, and of incorporating an appropriate discount rate, raise many challenges, and we do not attempt in this space to meet those challenges. For combating the harms produced by climate change, a separate fund for the assistance of those most at risk, accompanying reductions in greenhouse gases, may well be a good place to start. Such a fund could be used to promote further reductions and also to help nations that most suffer from climate change-by, for example, furnishing technological assistance or otherwise facilitating adaptations to hotter climates."

Of course creation of a fund does not answer the question of its magnitude, and it says nothing about the appropriate size of emissions reductions. It is also possible that the feasible steps to assist adaptation would not be adequate, and that aggressive prevention is therefore preferable. Our only claim is that the question of obligations to future generations must be answered directly.

\section{CONCLUSION}

The debate over discounting regulatory benefits has become both vigorous and exceedingly complicated. In our view, both advocates and critics of discounting have neglected a central point. If the question involves latent harms, the initial issue is how much people are willing to pay to prevent those harms. There is a difference between cases in which people are now being asked about their willingness to pay current amounts for future harms (a question that can be asked without any government discounting at all) and cases in which future willingness to pay is involved. So long as monetary values are assigned to the relevant variables, it is only money, and not any variable, that is being discounted. If a discount rate is properly applied to money, it is properly applied to the future money that public or private actors are willing to devote to regulatory benefits. There is no need for a separate assessment of the discount rate applied to latent harms. What is being discounted is the money that is used to combat those harms.

131 See Posner, Catastrophe at 151-52 (cited in note 9) ("A discount rate based on market interest rates tends to obliterate the interest of remote future generations.").

132 Possible approaches are discussed in detail in Stern Review at 308-568 (cited in note 29). 
In many respects, agency valuations of latent harms may be too low-perhaps because they do not consider national income growth, perhaps because cancer risks deserve particular attention, ${ }^{133}$ perhaps because they do not include the valuations of those whose friends and family members are at risk. ${ }^{134}$ But as a general rule, it should not be controversial to apply the monetary discount rate to monetized regulatory benefits, simply because no one doubts that money should be discounted. ${ }^{135}$

It is true that cost-benefit analysis with discounting, no less than cost-benefit analysis of any kind, can produce a net welfare loss, significant distributional difficulties, or both. For this reason, decisions based on that form of analysis can create severe ethical problems. But a refusal to discount might well fail to solve those problems. It might even aggravate them, either by impoverishing the present (to the detriment of the future) or by requiring the delay of life-saving programs (also to the detriment of the future). Current generations do owe moral duties to posterity, and it is important to prevent actions that impose serious losses on those who will follow. But the problem of intergenerational equity should be engaged directly. It should not be conflated with the question of discounting.

133 See James K. Hammitt and Jin-Tan Liu, Effects of Disease Type and Latency on the Value of Mortality Risk, $28 \mathrm{~J}$ Risk \& Uncertainty 73, 80 (2004) ("The value of preventing a fatal cancer is often considered to be greater than the value of preventing a fatal trauma in a workplace or transportation accident."); Revesz, 99 Colum L Rev at 972-73 (cited in note 8) (arguing that analysts undervalue cancer risks because they underestimate the morbidity that precedes mortality and they undervalue the "dread" factor). Some people, however, have expressed skepticism about the argument for adjustments. See EPA, An SAB Report on EPA's White Paper Valuing the Benefits of Fatal Cancer Risk Reduction (July 27, 2000) online at http://www.epa.gov/science1/pdf/eeacf013.pdf (visited Jan 23, 2007) ("[T] ments to the VSL for differences in age, health status, or risk aversion.").

134 See Eric A. Posner and Cass R. Sunstein, Dollars and Death, 72 U Chi L Rev 537,539-40 (2004) (emphasizing the need to consider those valuations and noting that "[t]ort law has long focused on the compensation of those still living," while "regulatory policy ... is concerned above all with producing the right deterrent signal, a concern that might seem to explain the use of a single, uniform number for the valuation of what matters most: the loss of life").

135 As we have noted, bounded rationality, especially in the form of hyperbolic discounting, may suggest that people's valuations must be adjusted. 